\title{
Control agents on the quality of Africanized honeybee queens
}

\section{Agentes de controle sobre a qualidade de rainhas de abelhas africanizadas}

\author{
Michele Potrich ${ }^{1 *}$; Fernanda Caroline Colombo ${ }^{2}$; Adriane Cristina Zanon ${ }^{3}$; Everton \\ Ricardi Lozano'; Rodrigo Mendes Antunes Maciel'; Flavia Galvan Tedesco ${ }^{2}$; \\ Marisa Clemente Rodrigues ${ }^{4}$; Fabiana Martins Costa-Maia ${ }^{5}$
}

\section{Highlights:}

B. bassiana increased the weight of the queens and reduced emergency time.

Other queens' morphometric parameters had no changes caused by the control agents.

The control agents did not interfere in villi height and breeding area.

The control agents did not interfere in the quality of Africanized honeybee queens.

\begin{abstract}
The objective of this study was to evaluate the effect of the entomopathogenic fungus Beauveria bassiana, used in large field crops, and of the pomegranate Punica granatum aqueous extract, with insecticidal potential for insect control, on the quality of Africanized Apis mellifera queens. The control sample was composed of sterile distilled water with Tween ${ }^{\circledR}$. The treatments were incorporated into a voile fabric, covered with an acrylic plate and packed with queen rearing nucleus hive, so the worker bees could be in contact with control agents (B. bassiana and $P$. granatum). In the next day, frames with 30 cell cups for queen rearing with larvae were introduced to produce queens, which were monitored at moment of emergency. Measurements included live weight, wing size, abdomen size, thorax size, the time of emergence, and analysis of the breeding area size. Histological analyses of the hypopharyngeal glands of attendant worker bees and of the midgut of virgin queens were performed. There was no reduction in the weight of queens, no changes in the length, width, and height of their thoraxes, no changes in the width and length of the wing, and no changes in total length. However, B. bassiana increased the weight of the queens and reduced emergency time. The control agents did not interfere in villi height and breeding area. No differences were found in tissues when the treatments were compared with their control. P. granatum extract and the fungus $B$. bassiana did not interfere in the quality of Africanized A. mellifera queens.
\end{abstract}

Key words: Apis mellifera. Selectivity. Non-target organism. Entomopathogenic fungus. Plant extract.

\footnotetext{
${ }^{1}$ Profs. Drs., Coordenação de Ciências Biológicas, Laboratório de Controle Biológico, Universidade Tecnológica Federal do Paraná, UTFPR, Campus Dois Vizinhos, Dois Vizinhos, PR, Brasil. E-mail: michelepotrich@utfpr.edu.br; evertonlricardi@ utfpr.edu.br

2 Discentes do Curso de Mestrado do Programa de Pós-Graduação em Agroecossistemas, PPGSIS, UTFPR, Dois Vizinhos, PR, Brasil. E-mail: fer.colombo@hotmail.com; flaviagtedesco@gmail.com

3 Discente do Curso de Mestrado, Programa de Pós-Graduação em Agronomia, PPGAG, UTFPR, Pato Branco, PR, Brasil. E-mail: rudilinke@hotmail.com

4 Discentes do Curso de Mestrado, Programa de Pós-Graduação em Zootecnia, PPGZO, UTFPR, Dois Vizinhos, PR, Brasil. E-mail: rodrimaciel@hotmail.com; marisacrodrigues2@gmail.com

$5 \operatorname{Prof}^{\mathrm{a}} \mathrm{Dr}^{\mathrm{a}}$, Coordenação de Zootecnia, Unidade de Ensino e Pesquisa em Apicultura, UTFPR, Dois Vizinhos, PR, Brasil. E-mail: fabianamcosta@utfpr.edu.br

* Author for correspondence
} 


\section{Resumo}

O objetivo foi avaliar o efeito do fungo entomopatogênico Beauveria bassiana, usado em grandes culturas, e o extrato aquoso de romã Punica granatum, com potencial efeito inseticida para o controle de insetos, sobre a qualidade de rainhas de Apis mellifera africanizadas. A testemunha foi composta por água destilada esterilizada com Tween ${ }^{\circledR}$. Os tratamentos foram incorporados em um tecido tipo gaze, envolto em uma placa de acrílico e acondicionados no interior de colônias tipo minirrecrias, para que as operárias entrassem em contato com o agente testado (B. bassiana and P. granatum). No dia seguinte foram introduzidos sarrafos com 30 cúpulas com larvas para produção de rainhas, as quais foram monitoradas à emergência, mensurando peso vivo, comprimento e largura da asa e do abdome, comprimento, largura e altura do tórax, tempo de emergência e área de cria. Análises histológicas das glândulas hipofaringeanas das operárias amas e do mesêntero das rainhas virgens também foram realizadas. Não houve redução no peso das rainhas e no comprimento do tórax e tampouco alteração na largura e altura do tórax, comprimento e largura do abdome, comprimento e largura da asa e comprimento total. No entanto $B$. bassiana induziu aumento no peso das rainhas e redução no tempo de emergência. Os agentes não interferiram na altura das vilosidades do mesêntero e na área de cria. Na análise histológica não foram observadas diferenças nos tecidos quando os tratamentos foram comparados com as respectivas testemunhas. O extrato de $P$. granatum e o fungo $B$. bassiana não interferiram na qualidade de rainhas de $A$. mellifera africanizada.

Palavras-chave: Apis mellifera. Seletividade. Organismo não-alvo. Fungo entomopatogênico. Extrato vegetal.

Most cultivated plant species are pollinated by insects. The honeybee Apis mellifera L. (Hymenoptera: Apidae) directly or indirectly accounts for $73 \%$ of the pollination of cultivated plants and $42 \%$ of the 57 most planted plant species in the world (Freitas \& Silva, 2015). Bees can visit hundreds of flowers during each trip to gather pollen and nectar (Tautz, 2010) and are responsible for the production of honey, wax, propolis, royal jelly, pollen, and apitoxin (Freitas \& Pinheiro, 2012).

Brazil has diverse flora and climate variability zones with apicultural potential and with the possibility of producing honey. However, the decline of pollinators may reduce crop production. Pollinator decline can be caused by insecticides used in cultures, diseases, or parasitic insects that affect or diminish pollinator populations (CostaMaia, Lino-Lourenço, \& Toledo, 2010; Kaplan, 2012; Lu, Warchol, \& Callahan, 2012; Rucker \& Thurman, 2012; VanEngelsdorp et al., 2017).

Bees may be in contact with synthetic phytosanitary products used to control the mite Varroa destructor (Acari: Mesostigmata) or the greater wax moth Galleria mellonella (Lepidoptera: Pyralidae), in addition to products used in crops to control diseases and insects ( $\mathrm{Lu}$ et al., 2012). This contact may contribute to Colony Collapse Disorder (CCD), characterized by the sudden disappearance of bees, especially workers, even when the colony is under appropriate conditions for survival; when bees disappear, the various stages of the development cycle are abandoned (Lu et al., 2012; VanEngelsdorp et al., 2017).

With the emergence of insects resistant to several synthetic phytosanitary products, farmers have been seeking for alternative control methods that do not select populations of resistant pest insects, do not cause negative effects to the environment and animal health, and do not reduce or stimulate the disappearance of bees (Silva \& Brito, 2015). Alternatives include biological control and alternative control agents. These control methods are becoming common, but more studies are necessary to assess the possible effects of these agents on non-target organisms and bees, which already have been suffering from Colony Collapse Disorder 
(Meikle, Mercadier, Holst, Nansen, \& Girod, 2007; Caldararo, 2015; VanEngelsdorp et al., 2017).

Beauveria bassiana (Bals.) Vuill, 1912, and pomegranate aqueous extract (Punica granatum L., Punicaceae) are commonly analyzed as potential bio-insecticidal pest control (Gandhi, Pillai, \& Patel, 2010; Gandhi \& Pillai, 2011; Hamiduzzaman, Sinia, Guzman-Novoa, \& Goodwin, 2012; Roja, Elliott, \& Morales-Ramos, 2018). In addition, $B$. bassiana is already used commercially for insect control in several crops. Knowing that A. mellifera visits several crops treated with these control agents, studies have been carried out to check the effect of entomopathogenic fungi (Alves, Marchini, Pereira, \& Braumgratz, 1996; Al Mazra'awi, Shipp, Broadbent, \& Kevan, 2006; Al Mazra'awi, 2007; García-Fernández, Santiago-Álvarez, \& QuesadaMoraga, 2008; Potrich et al., 2018) and natural products (Damiani et al., 2011; Xavier et al., 2015; Potrich et al., 2020) for A. mellifera. However, there few studies that assessed the effect of these agents in the field, especially those related to the quality of Africanized A. mellifera queens. Thus, the objective of this research was to evaluate the effect of $B$. bassiana and $P$. granatum extract on the quality of Africanized A. mellifera queens.

The research was carried out at the Apiculture Teaching and Research Unit (UNEPE) and Biological Control Laboratory of the Federal University of Technology, Paraná, Campus Dois Vizinhos (UTFPR-DV). Three treatments were established: sterile distilled water with Tween $^{\circledR}$ $0.01 \%$ (nonionic surfactant and emulsifier) (control), entomopathogenic fungus $B$. bassiana (at concentration of $1.0 \times 10^{8}$ conidia. $\mathrm{mL}^{-1}$ ) and Pomegranate aqueous extract (at 5\%, 5g powder. 100 $\mathrm{mL}^{-1}$ water). Beauveria bassiana is used in large field crops often with $A$. mellifera. The $P$. granatum extract was selected because the main compound of the secondary metabolism has potential insecticide and, in previous scientific studies, was classified as an extract with insecticidal potential for insect control. Moreover, these control agents presented negative effect on Africanized A. mellifera workers when assessed under laboratory conditions (Potrich et al., 2018, 2020).

For this, 30 cell cups for queen rearing containing an Africanized A. mellifera worker larva each were placed on a frame at the upper part of each queen rearing nucleus hive (301, Iceal, Santa Catarina. Brazil), with one treatment. For the application of the treatments, we used a type of voile fabric that was drenched with $200 \mathrm{~mL}$ of the solution. The fabric was covered by an acrylic plate with which the workers came into contact, packed inside the queen rearing nucleus hive; one plate was used for each treatment and nucleus hive.

Four days after the introduction of the cell cups for queen rearing with the A. mellifera larvae, were selected 20 random workers to remove the hypopharyngeal gland and to carry out the histological analysis with qualitative evaluation. Ten days after the introduction of cell cups, the queen cells were taken to the climate chamber (EL111; Elotrolab, Sao Paulo, Brazil) for breeding (T $34 \pm 2^{\circ} \mathrm{C}$ and R.H. $60 \pm 5 \%$ ). The emergence of $A$. mellifera queens was monitored. Queens were then anaesthetized with $\mathrm{CO}_{2}$ until 120 seconds and measured to verify if the contact of the workers with the products interfered in the quality of queens (biological parameters). Measurements included live weight (mg), length and width of the wing and abdomen, length, width and height of the thorax, and total length (mm).

After evaluation of the biological parameters, five queens from each treatment were taken to the field, each one in a previously prepared hive. After seven days, the colonies were monitored to ensure acceptance of the introduced queens. When fertilization was confirmed, the mapping was carried out to measure the breeding area of each treatment. To measure this area, we used a methodology adapted from Al-Tikrity, Hillmann, Benton and Clarke (1971). The images obtained were filed and subsequently measured as breeding area in $\mathrm{cm}^{2}$, 
with Image Tool version 3.0. This procedure was performed every seven days for 35 days. The virgin queens that were not used to measure the area had their midguts examined in the histopathological analysis for quantitative assessment. For analysis of the hypopharyngeal glands and midguts, we used a histotechnical standard procedure and the slides were stained with hematoxylin/eosin.

The experimental design was completely randomized with three treatments and 30 repetitions each; each queen was considered an experimental unit. For the midgut villi analysis, we performed three treatments with 20 repetitions. The data were subjected to homogeneity and normality tests and an analysis of variance (ANOVA); the averages were compared by the Tukey's post hoc test. We accepted significance at $\mathrm{p}=0.05$. All statistics were performed in Assistat version 7.7 beta (Silva, 2014).

The Africanized A. mellifera queens did not have reduction in the live weight at emergence when fed by workers that were in contact with $P$. granatum extracts and $B$. bassiana fungus in comparison with the control. However, we verified an increase in the weight of queens that were fed by workers that were in contact with $B$. bassiana $(\mathrm{F}=24.36 ; \mathrm{df}=2,50 ; \mathrm{P}$ $<0.01)$ (Table 1).

\section{Table 1}

Weight at emergence, emergence time, thorax length, width and height, abdomen length and width, wing length and width, and total length $( \pm \mathrm{SE})$ of the thorax of Africanized $A$. mellifera queens after being fed by workers that were in contact with control agents.

\begin{tabular}{lcccc}
\hline \multicolumn{1}{c}{ Treatment } & Control $^{1}$ & P. granatum & B. bassiana & P \\
\hline Emerged queens & 18 & 14 & 21 & \\
Weight at emergence (mg) & $206.7 \pm 3.40 \mathrm{~b}$ & $210.5 \pm 9.09 \mathrm{ab}$ & $233.6 \pm 4.37 \mathrm{a}$ & $<0.01$ \\
Emergence time (min) & $1459.6 \pm 144.75 \mathrm{a}$ & $1350.7 \pm 121.06 \mathrm{a}$ & $736.1 \pm 124.74 \mathrm{~b}$ & $<0.01$ \\
Length of thorax (mm) & $4.1 \pm 0.12 \mathrm{~b}$ & $4.6 \pm 0.13 \mathrm{a}$ & $4.4 \pm 0.10 \mathrm{a}$ & $<0.01$ \\
Width of thorax (mm) & $4.4 \pm 0.06 \mathrm{a}$ & $4.6 \pm 0.13 \mathrm{a}$ & $4.4 \pm 0.09 \mathrm{a}$ & 0.61 \\
Height of thorax (mm) & $4.8 \pm 0.08 \mathrm{ab}$ & $4.9 \pm 0.07 \mathrm{a}$ & $4.6 \pm 0.06 \mathrm{~b}$ & $<0.01$ \\
Length of abdomen (mm) & $10.7 \pm 0.12 \mathrm{a}$ & $10.5 \pm 0.27 \mathrm{a}$ & $10.8 \pm 0.15 \mathrm{a}$ & 0.62 \\
Width of abdomen (mm) & $4.7 \pm 0.07 \mathrm{a}$ & $4.9 \pm 0.13 \mathrm{a}$ & $4.9 \pm 0.07 \mathrm{a}$ & 0.06 \\
Length of wing (mm) & $10.3 \pm 0.12 \mathrm{a}$ & $10.4 \pm 0.12 \mathrm{a}$ & $10.2 \pm 0.15 \mathrm{a}$ & 0.58 \\
Width of wing $(\mathrm{mm})$ & $3.4 \pm 0.06 \mathrm{a}$ & $3.4 \pm 0.09 \mathrm{a}$ & $3.5 \pm 0.05 \mathrm{a}$ & 0.52 \\
Total length $(\mathrm{mm})$ & $16.6 \pm 0.20 \mathrm{a}$ & $17.0 \pm 0.43 \mathrm{a}$ & $16.5 \pm 0.23 \mathrm{a}$ & 0.76 \\
\hline
\end{tabular}

${ }^{1}$ Control: sterile distilled water with Tween ${ }^{\circledR}$

Letters in the line indicate significant difference between the treatments, by the Tukey's test, $95 \%$ confidence interval. SE: Standard error.

The emergence time of the queens fed by workers in contact with $P$. granatum extract and sterile distilled water with Tween ${ }^{\circledR}$ treatments didn't differ from each other. However, the emergence time of the queens from the treatment with $B$. bassiana was lower than the observed for control $(\mathrm{F}=10.49$; $\mathrm{df}=$ 2, 50; $\mathrm{P}<0.01$ ) (Table 1).
The thorax length of queens fed by workers in contact with $P$. granatum and $B$. bassiana extracts was larger when compared to the control $(\mathrm{F}=6.39$; $\mathrm{df}=2,50 ; \mathrm{P}<0.01)$. However, the thorax width ( $\mathrm{F}$ $=2.94 ; \mathrm{df}=2,50 ; \mathrm{P}=0.61)$ and height did not differ from the control $(\mathrm{F}=6.83 ; \mathrm{df}=2,50 ; \mathrm{P}<0.01)$ (Table 1). 
The wing length morphometry $(\mathrm{F}=0.88 ; \mathrm{df}=2$, $50 ; \mathrm{P}=0.58)$, wing width $(\mathrm{F}=0.75 ; \mathrm{df}=2,50 ; \mathrm{P}$ $=0.52)$, abdomen length $(\mathrm{F}=0.50 ; \mathrm{df}=2,50 ; \mathrm{P}=$ $0.62)$ and width $(\mathrm{F}=3.05 ; \mathrm{df}=2,50 ; \mathrm{P}=0.06)$, and the total body length $(\mathrm{F}=0.29 ; \mathrm{df}=2,50 ; \mathrm{P}=0.76)$ of the queens were not significantly affected by the treatments (Table 1).

The midgut villi height of the queens from the treatments did not vary in relation to the villi height of the queens from the control $(\mathrm{F}=3.80 ; \mathrm{df}=2$,
57; $\mathrm{P}=0.03$ ) (Table 2). Similarly, the breeding area $\left(\mathrm{cm}^{2}\right)$ of the queens, after being fed by workers in contact with $B$. bassiana or $P$. granatum, was not affected $(\mathrm{F}=0.98 ; \mathrm{df}=2,27 ; \mathrm{P}=0.61)$ (Table 2).

In the qualitative analysis, the hypopharyngeal glands of workers that were in contact with the control agents (B. bassiana and P. granatum) had no structural differences when compared to the glands from the control group.

\section{Table 2}

Height $(\mu \mathrm{m})$ of the midgut villi and breeding area $\left(\mathrm{cm}^{2}\right)( \pm \mathrm{SE})$ of the queens after being fed by workers in contact with control agents

\begin{tabular}{lcc}
\hline Treatment & Height of the midgut villi $(\mu \mathrm{m})$ & Breeding $\left(\mathrm{cm}^{2}\right)$ \\
\hline Control $^{1}$ & $126.2 \pm 5.93 \mathrm{ab}$ & $297.7 \pm 8.96 \mathrm{a}$ \\
P. granatum $^{\text {B bassiana }}$ & $141.8 \pm 6.36 \mathrm{~b}$ & $217.9 \pm 8.83 \mathrm{a}$ \\
$\mathrm{P}$ & $119.1 \pm 5.55 \mathrm{a}$ & $235.2 \pm 8.78 \mathrm{a}$ \\
\hline
\end{tabular}

${ }^{1}$ Control: sterile distilled water with Tween ${ }^{\circledR}$

Letters in the columns indicate significant difference between the treatments, by the Tukey test, 95\% confidence interval.

SE: Standard error.

No studies on the morphology of A. mellifera queens in contact with biological or alternative control agents were found in the literature. However, morphometry can be an important factor in queen quality and in honey production. In this sense, the larger and heavier queen has a higher number of ovarioles; the larger ones are the spermathecae, which can store more spermatozoa and increase the production of honey. (Woyke, 1971; Oldroyd \& Goodman, 1990; VanEngelsdorp \& Otis, 2000; Kaspar, Klaus, \& Friedrich, 2007). In our study it was found that the weight of the queens ranged from 206.7 to $233.6 \mathrm{mg}$. The weight of virgin queens varies between 160.0 and $225.0 \mathrm{mg}$ (Akyol, Yeninar, Kaftanoglu, \& Ag, 2008; Uchôa et al., 2012; Souza, Bezzera-Laure, Francoy, \& Gonçalves, 2013; Souza et al., 2015), which resembles the observed for the queens from all treatments evaluated.
The development time of $A$. mellifera queens since the loss of the old queen until the emergence of a new one, under normal conditions, ranges from 12.5 to 18 days (Fell \& Morse, 1984; Tofilski \& Czekonska, 2004). In our research, the emergence time from laying eggs and larvae transfer (1 day for the cell cups for queen rearing) until the emergence of the queens under laboratory conditions ranged from 14 to 15 days. This is within the average observed in the studies carried out under normal conditions.

Although $B$. bassiana did not reduce the weight of queens, we found that those from the treatment presented higher weight than the control queens. The presence of an entomopathogenic fungus in the environment may have influenced the workers, forcing them to increase the food supply to care for the queens. This may also have reduced the 
emergence time, which was lower for the queens under $B$. bassiana treatment. It is possible that $B$. bassiana was considered a stressor agent in the colony, which caused the workers to more often feed the larvae that gave rise to the queens. However, it did not interfere in the morphometry of the queens, so it can be considered safe for bees. Also, when the colony is without a queen, accelerated emergency time can be a beneficial factor.

The thorax length was also higher in queens from the treatments with $B$. bassiana and P. granatum. In our study, the thorax length ranged from 4.1 to 4.6 $\mathrm{mm}$, the width varied between 4.4 and $4.6 \mathrm{~mm}$, and the height ranged from 4.6 to $4.9 \mathrm{~mm}$; these values are similar to those found in other studies (Tarpy, Hatch, \& Fletcher, 2000; Metorima, Costa-Maia, Halak, Parpinelli, \& Toledo, 2015).

The abdomen length of virgin queens normally presents variations from 9.4 to $11 \mathrm{~mm}$ (Faquinello et al., 2011; Metorima et al., 2015) and the width has an average variation of $4.6 \mathrm{~mm}$ (Faquinello et al., 2011). In our research, the abdomen length of queens when fed by workers in contact with the control agents ranged from 10.5 to $10.8 \mathrm{~mm}$ and width ranged from 4.8 to $5.0 \mathrm{~mm}$; this was within or above the average observed in previous research.

The possible contact with products did not cause side effects and/or deformation during the wing growth. Wing length ranged from 10.2 to $10.4 \mathrm{~mm}$ and wing width ranged from 3.4 to $3.5 \mathrm{~mm}$. Similar results were found for wings of Africanized $A$. mellifera virgin queens: length varied between 9.6 and $9.9 \mathrm{~mm}$ and width varied from 3.2 to $3.7 \mathrm{~mm}$ (Tarpy et al., 2000; Metorima et al., 2015).

Although few changes were observed in the body of the queens fed by workers in contact with the control agents, it does not mean that they were not contaminated by the agents. Thus, analyzing the hypopharyngeal glands is another important factor, because they are responsible for producing royal jelly, which is used to feed future queens. These glands are very long and are coiled under and over the brain, allowing the connection of many secretory cells that are linked to the axial duct. The secretory units of hypopharyngeal glands are spherical (acini or alveoli) and do not have any link among themselves. In this study, no structural differences were found in the hypopharyngeal glands of workers in contact with the control agents that could be adhered to or within these structures.

The midgut cells are structures responsible for the increase of the cell absorption surface, where most part of the food digestion and absorption of the digestion products occurs. These cells are often renewed due to the wear that can occur by intense secretory and absorptive activity; they may be altered, injured, or reduced if certain products are absorbed (Cruz-Landim, 2009), such as alternative and biological control agents. Changes and reductions in the midgut cells were not observed, demonstrating that the control agents did not provoke changes in the queens fed by workers in contact with the control agents.

The breeding area of the A. mellifera queens from the queen rearing nucleus hives that were in contact with the treatments was not affected, ranging from $217.9 \mathrm{~cm}^{2}$ (pomegranate extract) to $297.7 \mathrm{~cm}^{2}$ (water and Tween ${ }^{\circledR}$ control). Meikle et al. (2008) also did not observe changes in the $A$. mellifera breeding area when in contact with $B$. bassiana, but Meikle et al. (2007) observed that mass of adult bees changed over time in hives treated with either conidia formulation or powder alone, but the authors confirmed that change is expected in a dynamic system.

The entomopathogenic fungus, B. bassiana, and $P$. granatum extracts tested in our study did not cause negative interference in the time of emergence of $A$. mellifera queens, nor did they interfere with the morphometric parameters or the size of the breeding area. Workers of A. mellifera have a hygienic behavior, so when in contact with the agents, they may have increased cleaning activity to try to combat them. In case the colony or the workers are contaminated by these agents, and 
even if they feed the queen with royal jelly and also come in contact with B. bassiana and P. granatum, they would not harm the colony in relation to queen quality and the breeding area and, consequently, the production of honey. Thus, theses control agents being able to be used in the field, in the control of insect-pests, being selective to the colonies of Africanized A. mellifera. New studies with different control agents and implementation methods should be considered to verify the influence on honeybees to prevent mortality and/or disappearance of colonies.

\section{Acknowledgements}

For Fundação Araucária for funding the project (25,383 - Agreement 229/2013).

\section{References}

Akyol, E., Yeninar, H., Kaftanoglu, O., \& Ag, A. (2008). Live weight of queen honey bees (Apis mellifera $\mathrm{L}$.) predicts reproductive characteristics. Journal of the Kansas Entomological Society, 81(2), 92-100. doi: 10.2317/JKES-705.13.1

Al Mazra'awi, M.(2007). Impact of the entomopathogenic fungus Beauveria bassiana on the honey bees, Apis mellifera (Hymenoptera: Apidae). World Journal of Agricultural Sciences, 3(1), 7-11. Recuperado de https://www.idosi.org/wjas/wjas3(1).htm.

Al Mazra'awi, M. S., Shipp, J. L., Broadbent, A. B., \& Kevan, P. G. (2006). Dissemination of Beauveria bassiana by honey bees (Hymenoptera: Apidae) for control of tarnished plant bug (Hemiptera: Miridae) on canola. Environmental Entomology, 35(6), 1569-1577. doi: 10.1603/0046-225x(2006)35 [1569:dobbbh]2.0.co;2

Al-Tikrity, W. S., Hillmann, R. C., Benton, A. W., \& Clarke, W. W., Jr. (1971) A new instrument for brood measurement in a honey bee colony. American Bee Journal, 111(1), 20-21.

Alves, S. B., Marchini, L. C., Pereira, R. M., \& Braumgratz, L. L. (1996). Effects of some insect pathogens on the Africanized honey bee, Apis mellifera L. (Hym., Apidae). Journal Applied of Entomology, 120(1), 559-564. doi: 10.1111/j.14390418.1996.tb01652.x
Caldararo, N. (2015). Social behaviour and the superorganism: implications for disease and stability in complex animal societies and colony collapse disorder in honeybees. Interdisciplinary Description of Complex Systems, 13(1), 82-98. doi: 10.7906/ indecs.13.1.10

Costa-Maia, F. M., Lino-Lourenço, D. A., \& Toledo, V. A. (2010). Aspectos econômicos e sustentáveis da polinização por abelhas. In T. N. Martin, A. J. Waclawovsky, F. Kuss, A. S. Mendes, \& E. J. Brun (Eds.), Sistemas de produção agropecuária (ciências agrárias, animais e florestais) (pp. 45-67). Dois Vizinhos: UTFPR.

Cruz-Landim, C. (2009) Abelhas: morfologia e função dos sistemas. São Paulo: UNESP.

Damiani, N., Gende, L. B., Maggi, M. D., Palacios, S., Marcangeli, J. A., \& Eguaras, M. J. (2011). Repellent and acaricidal effects of botanical extracts on Varroa destructor. Parasitology Research, 108(1), 79-86. doi: 10.1007/s00436-010-2043-3

Faquinello, P., Toledo, V. de A. A. de, Martins, E. N., Oliveira, C. A. L. de, Sereia, M. J., Costa-Maia, F. M., \& Ruvolo-Takasusuki, M. C. C. (2011). Parameters for royal jelly production in Africanized honeybees. Sociobiology, 57(3), 495-510. doi: 10.12795/spal.2002.i11.21.

Fell, R. D., \& Morse, R. A. (1984). Emergency queen cell production in the honey bee colony. Insectes Sociaux, 31(3), 221-237. doi: 10.1007/BF02223608

Freitas, B. M., \& Pinheiro, J. N. (2012). Polinizadores e pesticidas: princípios de manejo para os agroecossistemas brasileiros. Brasília: MMA.

Freitas, B. M., \& Silva, C. I. (2015) O papel dos polinizadores na produção agrícola no Brasil. In Associação Brasileira de Estudos das Abelhas A.B.E.L.H.A., Agricultura e polinizadores (pp. 9-18). São Paulo, SP: A.B.E.L.H.A.

Gandhi, N. \& Pillai, S. (2011). Control of Rhyzopertha dominica (Coleoptera: Bostrichidae) by pulverized leaves of Punica granatum (Lythraceae) and Murraya koenigii (Rutaceae). International Journal of Agriculture and Biology, 13(4), 535540. Recuperado de http://www.fspublishers. org $/$ search_list2.php?title $=$ Control $\% 20$ of $\% 20$ Rhyzopertha\%20dominica\%20(Coleoptera:\%20 Bostrichidae)\%20by $\% 20$ pulverized $\% 20$ leaves $\% 20$ of $\% 20$ Punica $\% 20$ granatum $\% 20$ (Lythraceae) $\% 20$ and\%20Murraya\%20koenigii\%20(Rutaceae) 
Gandhi, N., Pillai, S., \& Patel, P. (2010) Efficacy of pulverized Punica granatum (Lythraceae) and Murraya koenigii (Rutaceae) leaves against stored grain pest Tribolium castaneum (Coleoptera: Tenebrionidae). International Journal of Agriculture and Biology, 12(4), 616-620. Recuperado de http://www.fspublishers.org/search_list2.php? title $=$ Efficacy $\% 20$ of $\% 20$ pulverized $\% 20$ Punica $\% 20$ granatum $\% 20$ (Lythraceae) $\% 20$ and $\% 20$ Murraya\%20koenigii\%20(Rutaceae) \%20 leaves $\% 20$ against $\% 20$ stored $\% 20$ grain $\% 20$ pest $\% 20$ Tribolium\%20castaneum\%20(Coleoptera:\%20 Tenebrionidae)

García-Fernández, P., Santiago-Álvarez, C., \& QuesadaMoraga, E. (2008). Pathogenicity and thermal biology of mitosporic fungi as potential microbial control agents of Varroa destructor (Acari: Mesostigmata), an ectoparasitic mite of honey bee, Apis mellifera (Hymenoptera: Apidae). Apidologie, 39(6), 662-673. doi: 10.1051/apido

Hamiduzzaman, M. M., Sinia, A., Guzman-Novoa, E., \& Goodwin, P. H. (2012). Entomopathogenic fungi as potential biocontrol agents of the ecto-parasitic mite, Varroa destructor, and their effect on the immune response of honey bees (Apis mellifera L.). Journal of Invertebrate Pathology, 111(3), 237-243. doi: 10.1016/j.jip.2012.09.001

Kaplan, J. (2012). Colony collapse disorder: an incomplete puzzle. Agricultural Research, 18(7), 4-8. Recuperado de https://agresearchmag.ars.usda. gov/2012/jul/colony.

Kaspar, B., Klaus, E., \& Friedrich, R. (2007). Genetic evaluation in the honey bee considering queen and worker effects - A BLUP-Animal Model approach. Apidologie, 38(1), 77-85. doi: 10.1051/ apido:2006050

Lu, C., Warchol, K. M., \& Callahan, R. A. (2012). In situ replication of honey bee colony collapse disorder. Bulletin of Insectology, 65(1), 99-106. Recuperado de http://www.bulletinofinsectology.org/pdfarticles/ vol65-2012-099-106lu.pdf

Meikle, W. G., Mercadier, G., Holst, N., Nansen, C., \& Girod, V. (2007). Duration and spread of an entomopathogenic fungus, Beauveria bassiana (Deuteromycota: Hyphomycetes), used to treat varroa mites (Acari: Varroidae) in honey bee (Hymenoptera: Apidae) hives. Journal of Economic Entomology, 100(1), 1-10. doi: 10.1603/00220493(2007)100

Meikle, W. G., Mercadier, G., Holst, N., Nansen, C., \& Girod, V. (2008). Impact of a treatment of Beauveria bassiana (Deuteromycota: Hyphomycetes) on honeybee (Apis mellifera) colony health and on Varroa destructor mites (Acari: Varroidae). Apidologie, 39(2), 247-259. doi: 10.1051/apido:2007057

Metorima, F. N., Costa-Maia, F. M., Halak, A. L., Parpinelli, R. S., \& Toledo, V. A. (2015). Morphometric measurements of Africanized honeybee queens kept in an incubator or in queen banking. Acta Scientiarum. Animal Sciences, 37(1), 91-96. doi: 10.4025/actascianimsci.v37i1.24006

Oldroyd, B. P., \& Goodman, R. D. (1990). On the relative importance of queens and workers to honey production. Apidologie, 21(2), 153-159. doi: 10.1051/apido:19900209

Potrich, M., Silva, R. T. L., Costa-Maia, F. M., Lozano, E. R., Rossi, R. M., Colombo, F. C., \& Gouvea, A. de. (2018). Effect of entomopathogens on Africanized Apis mellifera L. (Hymenoptera: Apidae). Revista Brasileira de Entomologia, 62(1), 5-12. doi: 10.1016/j.rbe.2017.12.002

Potrich, M., Silva, R. T. L., Maciel, R. M. A., Costa-Maia, F. M. C., Lozano, E. R., Rossi, R. M., Dallacort, S. (2020). Are plant extracts safe for honey bees (Apis mellifera)? Journal of Apicultural Research. doi: 10.1080/00218839.2020.1735733

Roja, M. G., Elliott, R. B., \& Morales-Ramos, J. A. (2018) Mortality of Solenopsis invicta workers (Hymenoptera: Formicidae) after indirect exposure to spores of three entomopathogenic fungi. Journal of Insect Science, 18(3), 1-8. doi: 10.1093/jisesa/ iey 050

Rucker, R. R., \& Thurman, W. N. (2012). Colony collapse disorder: the market response to the bee disease. Montana: PERC Policy Series. Recuperado de https://www.perc.org/wp-content/uploads/old/ ps50.pdf.

Silva, A. B., \& Brito, J. M. (2015). Controle biológico de insetos-pragas e suas perspectivas para o futuro. Agropecuária Técnica, 36(1), 248-258. doi: 10.25066/agrotec.v36i1.26306

Silva, F. A. S. Assistat 7.7. (2014) Software estatístico. Campina Grande, PB: Assistência Estatística, Departamento de Engenharia Agrícola do CTRN Universidade Federal de Campina Grande.

Souza, D. A. de, Bezzera-Laure, M. A. F., Francoy, T. M., \& Gonçalves, L. S. (2013). Experimental evaluation of the reproductive quality of Africanized queen bees (Apis mellifera) on the basis of body weight at emergence. Genetics and Molecular Research, 12(4), 5382-5391. doi: 10.4238/2013.November.7.13 
Souza, D. A. de, Wang, Y., Kaftanoglu, O., De Jong, D., Amdam, G. V., Gonçalves, L. S., \& Francoy, T. M. (2015). Morphometric identification of queens, workers, intermediates in in vitro reared honey bees (Apis mellifera). PLoS ONE, 10(4), 1-15. doi: 10.1371/journal.pone.0123663

Tarpy, D., Hatch, S., \& Fletcher, D. (2000). The influence of queen age and quality during queen replacement in honeybee colonies. Animal Behaviour, 59(1), 97101. doi: 10.1006/anbe.1999.1311

Tautz, F. (2010). O Fenômeno das abelhas. São Paulo, SP: Artmed.

Tofilski, A., \& Czekonska, K. (2004). Emergency queen rearing in honeybee colonies with brood of known age. Apidologie, 35(3), 275-282. doi: 10.1051/apido :2004014

Uchôa, F. de A. B., Souza, D. C., Alves, A. A., Silva, F. A. S., Moura, J. de A., Nunes, J. R. A., \& Sousa, J. da S. (2012). Effect of weight of Africanized queens (Apis mellifera L.) at birth in honey production in semi-arid Piauiense. Agropecuária Científica no Semiárido, 8(1), 1-6. doi: 10.30969/acsa.v8i2.172
vanEngelsdorp, D., \& Otis, G. W. (2000). Application of a modified selection index for honey bees (Hymenoptera: Apidae). Journal of Economic Entomology, 93(6), 1606-1612. doi: 10.1603/00220493-93.6.1606

vanEngelsdorp, D., Traynor, K. S., Andree, M., Lichtenberg, E. M., Chen, Y., Saegerman, C., \& Cox-Foster, D. L. (2017). Colony Collapse Disorder (CCD) and bee age impact honey bee pathophysiology. PLOS ONE, 12(7), 1-24. doi: 10.1371/journal.pone.0179535

Woyke, J. (1971). Correlations between the age at which honeybee brood was grafted, characteristics of the resultant queens, and results of insemination. Journal of Apicultural Research, 10(1), 45-55. doi: 10.1080/00218839.1971.11099669

Xavier, V. M., Message, D., Picanço, M. C., Chediak, M., Santana, P. A., Jr., Ramos, R. S., \& Martins, J. C. (2015). Acute toxicity and sublethal effects of botanical insecticides to honey bees. Journal of Insect Science, 15(1), 1-6. doi: 10.1093/jisesa/iev110 
